\title{
Efektivitas Pemberian Bakteri Bacillus amyloliquefaciens sebagai Biofertilizer terhadap Pertumbuhan Sorgum Mutan Brown Midrib (Sorghum bicolor L. Moench) di Tanah Ultisol
}

\section{The effects of Bacillus amyloliquefaciens Bacteria as Biofertilizer on Growth of Brown Midrib Sorghum Mutant Line (Sorghum bicolor L. Moench) in Ultisol}

\author{
R. Sriagtula ${ }^{1 *}$, Q. Aini ${ }^{1}$, dan R. Jannah ${ }^{2}$ \\ ${ }^{1}$ Bagian Ilmu Nutrisi dan Teknologi Pakan, Fakultas Peternakan, Universitas Andalas, Padang - Indonesia \\ ${ }^{2}$ Program Studi Peternakan, Fakultas Peternakan, Universitas Andalas, Padang - Indonesia \\ *Corresponding E-mail: riesisriagtula@ansci.unand.ac.id \\ (Diterima: 23 November 2020; Disetujui: 27 April 2021)
}

\begin{abstract}
ABSTRAK
Sorgum Brown Midrib (BMR) dapat beradaptasi dengan berbagai rentang $\mathrm{pH}$ tanah termasuk tanah asam. Penelitian ini bertujuan untuk mengobservasi efektivitas pemberian bakteri Bacillus amyloliquefaciens untuk meningkatkan efisiensi pupuk fosfat $(\mathrm{P})$ terhadap pertumbuhan tanaman sorgum mutan BMR hingga fase generatif. Penelitian dilakukan di kebun Laboratorium Percobaan Fakultas Peternakan Universitas Andalas Padang, menggunakan Rancangan Acak Kelompok (RAK) terdiri dari 4 perlakuan dan 4 kelompok sebagai ulangan. Perlakuan terdiri dari : $\mathrm{P}_{0}=\mathrm{Urea}+\mathrm{KCl}+0 \% \mathrm{TSP}+$ B. amyloliquefaciens $\mathrm{F}$; $\mathrm{P}_{1}=\mathrm{Urea}+\mathrm{KCl}+50 \% \mathrm{TSP}+$ B. amyloliquefaciens; $\mathrm{P}_{2}=\mathrm{Urea}+\mathrm{KCl}+75 \% \mathrm{TSP}+$ B. amyloliquefaciens; $\mathrm{P}_{3}=\mathrm{Urea}+\mathrm{KCl}+100 \%$ TSP (Tanpa B. amyloliquefaciens). Biakan B. amyloliquefaciens berasal dari probiotik Waretha dengan dosis $10 \mathrm{ml} /$ lubang tanam setara dengan $10^{7} \mathrm{cfu} / \mathrm{g}$. Parameter yang diukur yaitu pertambahan tinggi tanaman, diameter batang, panjang dan lebar daun. Hasil penelitian menunjukkan pemberian bakteri $B$. amyloliquefaciens menunjukkan pengaruh berbeda tidak nyata $(\mathrm{P}>0,05)$ terhadap pertambahan tinggi tanaman, diameter batang, panjang dan lebar daun. Pertambahan tinggi tanaman sorgum mutan BMR berlangsung hingga umur 72 HST, sedangkan pertambahan diameter batang, panjang dan lebar daun berhenti pada 58 HST. Berdasarkan hasil penelitian dapat disimpulkan bahwa inokulasi $B$. amyloliquefaciens belum efektif meningkatkan pertumbuhan sorgum mutan BMR di tanah ultisol.
\end{abstract}

Kata kunci: Bacillus amyloliquefaciens, pertumbuhan tanaman, pupuk fosfor, sorgum mutan BMR, Waretha

\section{ABSTRACT}

Brown midrib (BMR) sorghum mutant can adapt to various soil $p H$ ranges, including acidic soils. This study aims to observe the effectiveness of B. amyloliquefaciens on the growth of the BMR sorghum mutant line until at the generative phase. The research was conducted in the Experimental Laboratory of the Faculty of Animal Science, Andalas University, Padang, using a randomized block design (RBD) consisting of 4 treatments and four groups as replications. The treatments consisted of: $\mathrm{PO}=\mathrm{Urea}+\mathrm{KCl}+$ $0 \% \mathrm{TSP}+$ B. amyloliquefaciens $; \mathrm{Pl}=$ Urea $+\mathrm{KCl}+50 \% \mathrm{TSP}+\mathrm{B}$. amyloliquefaciens $; \mathrm{P} 2=$ Urea $+\mathrm{KCl}$ $+75 \%$ TSP + B. amyloliquefaciens; $P 3=$ Urea $+K C l+100 \%$ TSP (without B. amyloliquefaciens). The $B$. amyloliquefaciens culture was derived from the Waretha probiotic with a dose of $10 \mathrm{ml} /$ planting hole is equivalent to $107 \mathrm{CFU}$ / gram. Parameters measured were the growth of plant height, stem diameter, leaf length, and leaf width. The results showed that the administration of B. amyloliquefaciens bacteria in all parameters showed insignificant differences $(P>0.05)$ on plant height, stem diameter, leaf length, and leaf width. The increase in the height of BMR mutant sorghum was measured up to 72 DAS, while the increase in stem diameter, length, and leaf width stopped at 58 DAS for all treatments. Based on the study results, it can be concluded that inoculation of B. amyloliquefaciens has not been effective in increasing the growth of BMR mutant sorghum in ultisol.

Keywords: Bacillus amyloliquefaciens, BMR sorghum mutant, Plant growth, Phosphorus fertilizer, Waretha 


\section{PENDAHULUAN}

Sorgum mutan BMR merupakan hasil mutasi genetik dengan iradiasi sinar gamma yang budidayanya diarahkan sebagai tanaman pakan ternak. Kandungan lignin Sorgum mutan BMR adalah 6\%, lebih rendah dibanding sorgum non BMR sehingga memiliki kecernaan yang lebih tinggi (Sriagtula et al., 2016; Sriagtula et al., 2017). Sorgum BMR dapat beradaptasi pada berbagai rentang $\mathrm{pH}$ tanah termasuk tanah asam (Getachew et al., 2016). Dewasa ini, varietas BMR semakin luas penggunaannya sebagai hijauan pakan karena dampaknya dalam menurunkan mitigasi gas metan pada pencernaan ternak ruminansia (Wahyono et $a l, 2019)$. Alih fungsi lahan akibat kompetisi dengan sektor industri maupun pemukiman menyebabkan budidaya tanaman pakan ternak seringkali dilakukan pada lahan kelas tiga dan empat yang mempunyai hambatan berat. Tanah ultisol merupakan salah satu jenis tanah dengan hambatan besar dan pemanfaatannya sebagai lahan pertanian di Indonesia belum terkelola dengan baik (Prasetyo dan Suriadikarta, 2006).

Tanah ultisol merupakan salah satu jenis tanah dengan $\mathrm{pH}$ rendah, dengan penyebaran sekitar 38,4 juta hektar atau 29,7\% dari 190 juta hektar luas daratan Indonesia (Masni et al., 2015). Tanah ultisol sering diidentikkan dengan tanah yang tidak subur, dimana mengandung bahan organik, hara dan $\mathrm{pH}$ rendah $<5,5$ dan memiliki ketersediaan $\mathrm{P}$ rendah (Fitriatin et al., 2014). Unsur Al dan Fe yang banyak larut pada tanah masam akan mengikat $\mathrm{P}$ sehingga tidak tersedia. $\mathrm{P}$ berperan dalam pertumbuhan, produksi dan proses metabolisme tanaman. Umumnya tanah ultisol di Indonesia merupakan lahan kering dan kurang produktif. Pembenahan tanah yang lebih ramah lingkungan dapat dilakukan dengan pupuk hayati.

Pupuk hayati (biofertilizer) mengandung mikroba bermanfaat yang dapat meningkatkan efisiensi pemupukan, kesuburan, dan kesehatan tanah (Kementan
2011). Jenis dan keberadaan mikroba probiotik menentukan nilai manfaat dari pupuk hayati (Paturrohman et al., 2017). Pupuk hayati disebut juga sebagai "plant growth promoting rhizobacteria" (PGPR) mengandung satu atau lebih strain bakteri yang menguntungkan (Malusa et al., 2012), serta mampu meningkatkan pertumbuhan tanaman dengan mengkolonisasi akar tanaman (Hayat et al., 2010). Bacillus sp. merupakan bakteri PGPR yang penting dalam penambahan hara tanaman melalui pelarutan fosfat yang mempengaruhi pertumbuhan tanaman. B. amyloliquefaciens berasal dari produk komersil Waretha dikenal sebagai probiotik pada ternak unggas (Wizna et al., 2017). Di samping sebagai probiotik, waretha berpotensi dimanfaatkan sebagai biofertilizer untuk mengatasi masalah ketersediaan fosfor di dalam tanah. Bakrie et al. (2010) menyatakan dosis pupuk anorganik pada tanaman padi dapat dikurangi hingga $50 \%$ dengan aplikasi pupuk hayati. Produksi akar lateral terukur meningkat dengan inokulasi B. amyloliquefaciens sebesar 51\% pada tanaman gandum (Talboys et al., 2014).

Efek pemupukan terhadap produksi dan tinggi tanaman sorgum sudah banyak dilaporkan (Masebo and Menamo, 2016; Sriagtula et al., 2016; Pannacci and Bartolini (2018). Simanjuntak et al. (2016) dan Dani (2017) melaporkan pertambahan tinggi tanaman sorgum selama fase vegeratif umur 42 HST - 56 HST. Namun informasi pertambahan tinggi tanaman sorgum lebih lanjut hingga fase generatif belum diinvestigasi. Berdasarkan pemikiran di atas perlu dilakukan penelitian yang bertujuan mengobservasi efektivitas pemberian bakteri $B$. amyloliquefaciens untuk meningkatkan efisiensi pupuk $\mathrm{P}$ terhadap peningkatan pertumbuhan tanaman sorgum mutan Brown Midrib (BMR) (Sorghum bicolor L. Moench) hingga fase generatif di tanah ultisol. 


\section{METODE}

\section{Materi Penelitian}

\section{Alat dan Bahan}

Alat yang digunakan dalam penelitian ini yaitu mesin bajak, cangkul, meteran, sprayer, timbangan, jangka sorong. Materi yang digunakan dalam penelitian ini adalah benih BMR yang diperoleh dari SEAMEOBIOTROP Bogor, pupuk kandang, Urea, TSP, $\mathrm{KCl}$, biakan $B$. amyloliquifaciens berasal dari probiotik Waretha dan pestisida merk Sidametrin.

\section{Metode Penelitian}

Penelitian menggunakan rancangan acak kelompok (RAK) dengan 4 perlakuan dan 4 kelompok sebagai ulangan. Perlakuan terdiri dari: $\mathrm{P}_{0}=$ Urea $+\mathrm{KCl}+0 \%$ TSP + B. amyloliquifaciens; $\mathrm{P}_{1}=\mathrm{Urea}+\mathrm{KCl}+$ $50 \%$ TSP + B. amyloliquifaciens; $\mathrm{P}_{2}=$ Urea $+\mathrm{KCl}+75 \% \mathrm{TSP}+$ B. amyloliquifaciens; $\mathrm{P}_{3}=$ Urea $+\mathrm{KCl}+100 \%$ TSP (Tanpa $B$. amyloliquifaciens). B. amyloliquifaciens berasal dari biakan probiotik waretha (Wizna, 2017) dengan kerapatan $10^{7} \mathrm{cfu} / \mathrm{g}$ dengan dosis $10 \mathrm{ml} /$ lubang tanam modifikasi dosis Sariwahyuni (2012). Pupuk yang digunakan adalah Urea, TSP dan $\mathrm{KCl}$ terdiri dari $60 \mathrm{~kg} /$ ha, $90 \mathrm{~kg} / \mathrm{ha}$ dan $60 \mathrm{~kg} / \mathrm{ha}$ (Wahyono, 2019) dan pupuk kandang 10 ton/ha (Sriagtula et al., 2016). Hasil analisis tanah dan kondisi iklim selama penelitian disajikan pada Tabel 1 dan Gambar 1.

\section{Persiapan Lahan}

Lahan yang digunakan dalam penelitian diolah menggunakan mesin bajak kemudian ditambahkan pupuk kandang dengan dosis 10 ton/ha dan digemburkan. Plot-plot penelitian dibuat dengan ukuran $4 \mathrm{~m} \times 5 \mathrm{~m}$ sehingga terdapat 16 plot penelitian. Hasil analisis tanah menunjukkan $\mathrm{pH}$ 4,5 (masam) dengan kandungan $\mathrm{P}$ tersedia tergolong sangat rendah $9.61 \mathrm{ppm}$ (Tabel 1).

\section{Penanaman}

Penanaman benih sorghum dilakukan satu bulan setelah pengolahan tanah secara tugal dengan jarak $20 \times 60 \mathrm{~cm}$ (Sriagtula et al., 2016), sehingga terdapat 166 lubang untuk tiap plot penelitian. Tiap lubang ditanam 3 benih sorgum dengan kedalaman 5 $\mathrm{cm}$, kemudian dilakukan penjarangan dengan menyisakan dua tanaman per lubang tanam.

\section{Persiapan probiotik waretha sebagai biofertilizer}

Biofertilizer berasal dari probiotik Waretha yang mengandung strain bakteri $B$. amyloliquifaciens. Waretha diaplikasikan dalam bentuk kultur cair dengan populasi bakteri $10^{7} \mathrm{cfu} / \mathrm{g}$ menggunakan Metode Total Plate Count (Dwidjoseputro, 2005). Sebanyak $10 \mathrm{~g}$ Waretha dilarutkan dalam 90 $\mathrm{ml}$ aquadest steril. Isi 6 buah test tube masingmasing sebanyak $9 \mathrm{ml}$ aquadest selanjutnya disterilkan dalam autoclave selama 30 menit pada suhu $121^{\circ} \mathrm{C}$. Setelah dingin, pipet 1 $\mathrm{ml}$ larutan sampel masukkan ke dalam test tube 1 , kemudian dihomogenkan sehingga diperoleh pengenceran $10^{2}$. Pipet sebanyak

Tabel 1. Data Analisa Tanah Awal

\begin{tabular}{clccc}
\hline No & Parameter Analisis & Satuan & Tanah & Keterangan \\
\hline 1 & $\mathrm{pH}$ & & 4,5 & Masam \\
2 & P total & Ppm & 6,987 & Sedang \\
3 & N total & $\%$ & 0,504 & Sedang \\
4 & P tersedia & Ppm & 9,61 & Sangat Rendah \\
5 & K total & $\mathrm{Me} / 100 \mathrm{~g}$ & 0,04 & Rendah \\
\hline
\end{tabular}

Keterangan: Hasil analisis Laboratorium Tanah, Fakultas Pertanian, Universitas Andalas (2020). $\mathrm{N}=$ Nitrogen, $\mathrm{P}=$ Fosfor, $\mathrm{K}=$ Kalium 

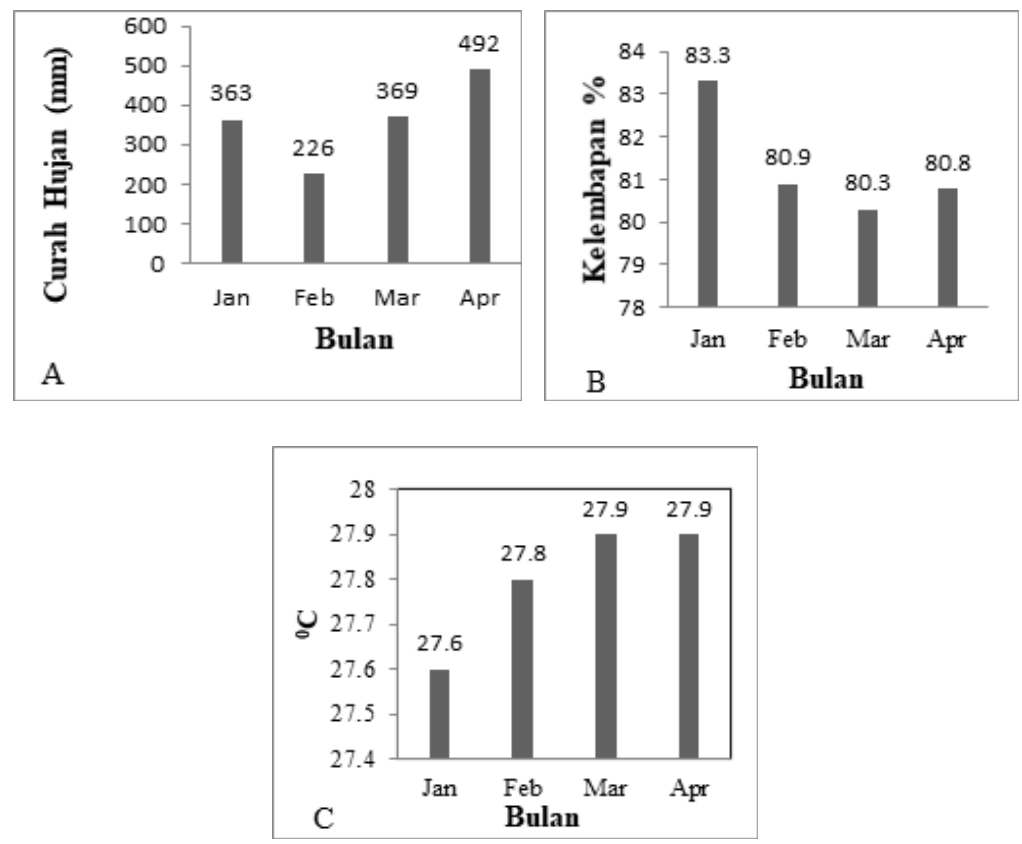

Gambar 1. Kondisi iklim selama penelitian: (A) Rataan curah hujan, (B) Rataan kelembapan relatif, (C) Temperatur udara. Sumber: BMKG Stasiun Klimatologi Padang Pariaman, 2020.

$1 \mathrm{ml}$ pengenceran $10^{2}$ pindahkan ke test tube berikutnya dan dihomogenkan. Lakukan seterusnya hingga diperoleh pengenceran $10^{7}$. Proses kultur bakteri dilakukan dengan metode permukaan, sebelumnya dibuat media agar dengan cara menyiapkan $100 \mathrm{ml}$ media khusus Bacillus sp, kemudian dipanaskan hingga mendidih. Setelah dingin (suhu 47$50^{\circ} \mathrm{C}$ ), pipet $1 \mathrm{ml}$ sampel dari pengenceran $10^{7}$ pada permukaan agar pada petri steril kemudian diratakan. Inkubasi pada suhu $36^{\circ} \mathrm{C}$ selam 24 jam.

Kultur murni yang di isolasi dari Waretha, ditumbuhkan dalam media Bacillus sp selama 48 jam dan di hitung total koloninya. Kemudian dilakukan pengenceran dan ditumbuhkan kembali sampai jumlah koloni sesuai yang di inginkan.

\section{Pemeliharaan}

Pemberian pupuk urea dilakukan sebanyak dua kali yaitu 14 hari setelah tanam (HST) sebanyak $2 / 3$, sisanya diberikan 40 HST. Pupuk TSP dan $\mathrm{KCl}$ diberikan sekaligus pada saat 14 HST (Sriagtula et al., 2017).
Pemberian pupuk dilakukan dengan cara membuat lubang sedalam 5-10 cm di samping tanaman, pupuk dimasukkan ke dalam lubang kemudian ditutup dengan tanah.

\section{Parameter yang Diamati}

Parameter terdiri dari pertambahan tinggi tanaman, diameter batang, panjang daun dan lebar daun.

\section{Analisis Data}

Data yang diperoleh, dianalisis varians menurut RAK menggunakan software SPSS 20.

\section{Prosedur Pengukuran Parameter}

Tanaman yang diamati berasal dari 10 tanaman yang dipilih secara acak dari setiap plot. Sepuluh tanaman sampel diberi tanda sehingga pengukuran dilakukan pada tanaman yang sama. Pengukuran pertumbuhan dilakukan secara periodik pada umur 30 HST hingga 72 HST dengan interval waktu 14 hari $(30,44,58,72$ HST). Tinggi tanaman diukur dari pangkal batang di permukaan tanah sampai ujung tanaman tertinggi menggunakan 
meteran. Diameter pangkal batang dilakukan dengan mengukur tepat pada bagian pangkal batang menggunakan jangka sorong. Panjang dan lebar daun diukur pada daun yang sudah membuka sempurna dan diukur secara periodik pada daun sama. Lebar daun diukur menggunakan meteran pada bagian tengah daun yang terlebar. Panjang daun, diukur pada daun terpanjang mulai dari colar (ketiak daun) sampai ujung daun.

\section{HASIL DAN PEMBAHASAN}

\section{Pengaruh Perlakuan Terhadap Pertambahan Tinggi dan Diameter Batang Sorgum Mutan BMR}

Hasil Penelitian menunjukkan bahwa perlakuan pemberian bakteri $B$. amyloliquefaciens berpengaruh tidak nyata $(\mathrm{p}>0,05)$ terhadap pertambahan tinggi tanaman dan diameter batang sorgum mutan BMR. Pertambahan tinggi tanaman dan diameter batang yang hampir sama disebabkan koloni bakteri $B$. amyloliquefaciens yang ditambahkan lebih rendah yaitu $10^{7} \mathrm{cfu} / \mathrm{g}$ dan belum bisa mendominasi dan bersaing dengan mikroorganisme asli tanah, sehingga aktivitasnya dalam melarutkan fosfat belum terlihat. Seperti pernyataan Suriadikarta et al. (2006) bahwa pemberian inokulan pelarut fosfat harus dengan kepadatan yang tinggi lebih dari $10^{8}$ sel gram ${ }^{-1}$ media pembawanya, sehingga bakteri pelarut fosfat (BPF) yang diberikan dapat bersaing dan mampu mendominasi disekitar perakaran tanaman. Suliasih et al. (2010) melaporkan pemberian inokulan BPF dengan konsentrasi $10^{9}$ sebagai pupuk hayati dapat meningkatkan populasi BPF dan aktivitas enzim fosfatase.

Pertambahan tinggi tanaman, diameter batang, panjang dan lebar daun pada semua perlakuan menunjukkan pengaruh yang berbeda tidak nyata. Pada penelitian ini tidak terlihat peningkatan kelarutan fosfat pada perlakuan yang mendapat inokulasi $B$. amyloliquefaciens ( $\mathrm{P} 0, \mathrm{P} 1$ dan $\mathrm{P} 2)$. Hal ini dibuktikan dengan kandungan fosfat tersedia yang terukur pada $\mathrm{P} 0, \mathrm{P} 1, \mathrm{P} 2$ hampir sama dengan P3 dan berada pada status sangat rendah dan rendah dengan nilai berturut-turut 5,42 ppm; 7,25 ppm; 5,88 ppm (sangat rendah) dan $10,75 \mathrm{ppm}$ (rendah). Kelarutan fosfat antara lain diindikasikan dengan penurunan pH tanah. Pada penelitian ini justru terjadi peningkatan kandungan $\mathrm{pH}$ tanah setelah penelitian pada perlakuan $\mathrm{P} 0, \mathrm{P} 1, \mathrm{P} 2$ dan $\mathrm{P} 3$ dengan nilai berturut-turut 5,$30 ; 5,47 ; 5,40$ dan 5,52, dibanding $\mathrm{pH}$ awal yaitu 4.5. Sesuai dengan Walpola et al. (2013) bahwa untuk melarutkan fosfat bakteri akan melepaskan asam organik sehingga terjadi penurunan $\mathrm{pH}$ lingkungan. Selain itu, peningkatan $\mathrm{pH}$ tanah setelah penelitian disebabkan respon fisiologis sorgum terhadap tanah masam dengan cara meningkatkan $\mathrm{pH}$ di daerah rizosfer agar fosfat menjadi tersedia dan dapat diserap akar. Sesuai dengan Sopandie (2014) bahwa toleransi tanaman terhadap tanah masam antara lain mampu meningkatkan $\mathrm{pH}$ tanah disekitar perakaran. Perlakuan dengan Penambahan $B$. amyloliquefaciens pada penelitian ini belum mampu meningkatkan pertumbuhan tanaman. $\mathrm{P}$ merupakan unsur yang berperan dalam pertumbuhan tanaman. Harris and Karmas (1989) menyatakan bahwa tanaman yang tumbuh pada tanah yang kekurangan $\mathrm{P}$ pertumbuhannya kurang baik, pucat, dan produksinya rendah. Mamanto (2005) menyatakan bahwa pupuk P sangat diperlukan untuk proses pembesaran diameter batang dan pembentukan akar yang akan menunjang berdirinya tanaman.

Pertambahan tinggi tanaman dan diameter batang selama penelitian disajikan pada Gambar 2 dan 3. Hasil pengamatan pertambahan tinggi tanaman sorgum mutan BMR yang diamati pada $30-72$ HST menunjukkan terjadi peningkatan cepat pertambahan tinggi tanaman pada umur 30-72 HST. Pada penelitian ini daun bendera muncul pada umur 50 HST, yang berarti tanaman mengakiri fase pertumbuhan vegetatif. Namun, hasilpengamatan menunjukkan terjadi peningkatan pertambahan tinggi tanaman hingga pengamatan pada 72 HST dimana 


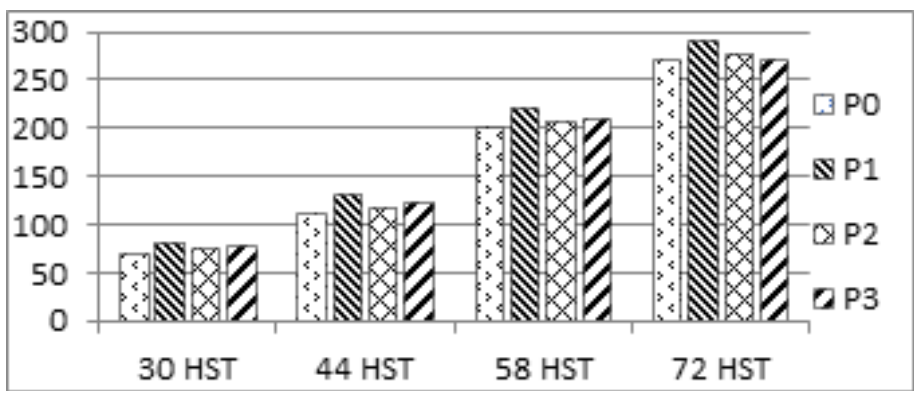

Gambar 2. Diagram pertambahan tinggi tanaman sorgum yang diberi bakteri Bacillus amyloliquefaciens dengan dosis pupuk fosfor berbeda pada 30-72 HST. $\mathrm{P}_{0}=$ Urea $+\mathrm{KCl}+0 \% \mathrm{TSP}+$ B. amyloliquifaciens; $\mathrm{P}=$ Urea $+\mathrm{KCl}+50 \% \mathrm{TSP}+B$. amyloliquifaciens; $\mathrm{P}_{2}=\mathrm{Urea}+\mathrm{KCl}+75 \% \mathrm{TSP}+B$. amyloliquifaciens; $\mathrm{P}_{3}=\mathrm{Urea}+$ $\mathrm{KCl}+100 \%$ TSP (Tanpa B. amyloliquifaciens).

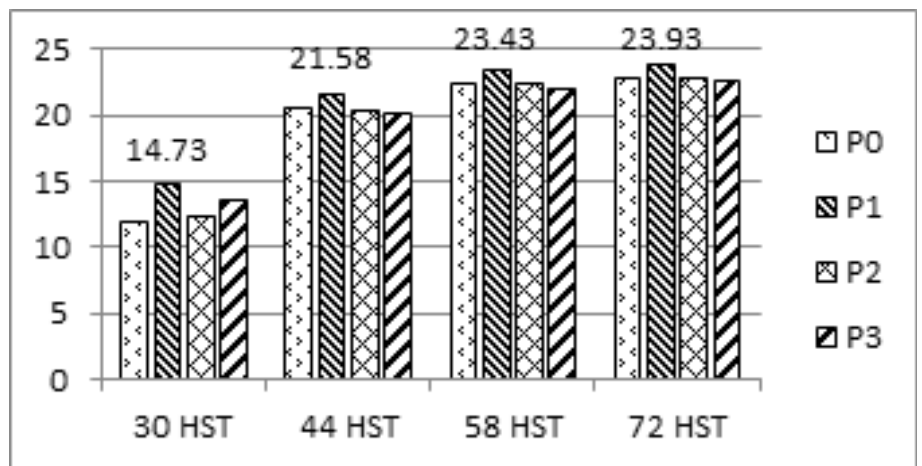

Gambar 3. Diagram pertambahan diameter batang tanaman sorgum yang diberi bakteri Bacillus amyloliquefaciens dengan dosis pupuk fosfor berbedapada 30-72 HST. $\mathrm{P}_{0}=\mathrm{Urea}+\mathrm{KCl}$ $+0 \% \mathrm{TSP}+$ B. amyloliquifaciens $; \mathrm{P}_{1}=\mathrm{Urea}+\mathrm{KCl}+50 \% \mathrm{TSP}+$ B. amyloliquifaciens; $\mathrm{P}_{2}=\mathrm{Urea}+\mathrm{KCl}+75 \%$ TSP + B. amyloliquifaciens; $\mathrm{P}_{3}=$ Urea $+\mathrm{KCl}+100 \%$ TSP (Tanpa B. amyloliquifaciens).

tanaman sudah berada pada fase genaratif(fase $50 \%$ berbunga). Akhir fase vegetatif ditandai dengan keluarnya daun bendera dan tangkai malai untuk inisisai bunga, serta berhentinya pertumbuhan vegetatif. Sesuai pernyataan Du-Plessis (2008) bahwa inisiasi bunga menandai akhir fase vegetatif dan dimulainya fase generatif atau reproduktif. Peningkatan laju pertambahan tinggi tanaman pada 72 HST merupakan proses perkembangan malai. Sesuai dengan Andriani dan Isnaini (2013) bahwa tangkai malai memanjang seiring dengan perkembangan malai, dan mendorong malai keluar dari pelepah daun bendera. Tangkai malai (peduncle) merupakan ruas paling ujung (terminal internode) yang menopang malai dan paling panjang, yang terdapat pada batang sorgum sehingga terjadi pertambahan tinggi tanaman sorgum pada fase generatif.

Pertumbuhan dan perkembangan diameter batang tidak berpengaruh nyata terhadap pemberian $B$. amyloliquefaciens dan dosis pupuk $\mathrm{P}$ berbeda, hal ini disebabkan pembelahan sel yang terus berlanjut dan juga merupakan akibat dari aktivitas meristem lateral (Champbell, 2002). Diameter batang terus bertambah sesuai pertumbuhan vegetatif tanaman hingga perlahan melambat dan berhenti seiring memasuki masa pertumbuhan generatif. Pada Gambar 3 terlihat peningkatan cepat penambahan diameter batang terjadi pada umur 30 HST sampai umur 44 HST, 


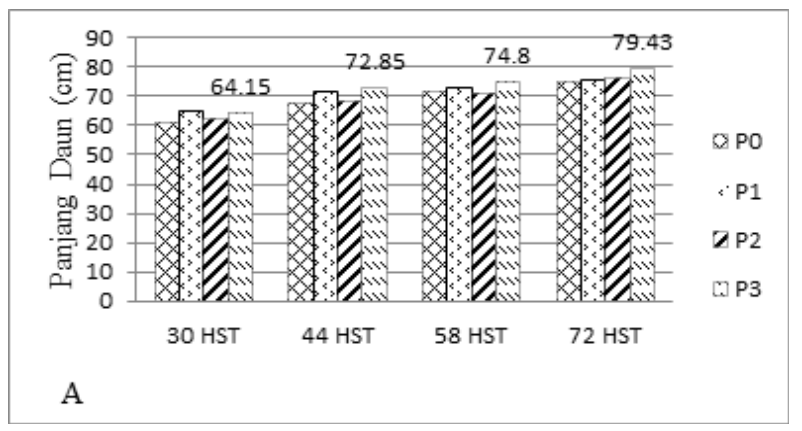

Gambar 4. Diagram pertambahan Panjang daun tanaman sorgum yang diberi bakteri Bacillus amyloliquefaciens dengan dosis pupuk fosfor berbeda pada 30-72 HST. $\mathrm{P}_{0}=\mathrm{Urea}+\mathrm{KCl}$ $+0 \% \mathrm{TSP}+$ B. amyloliquifaciens $; \mathrm{P}_{1}=\mathrm{Urea}+\mathrm{KCl}+50 \% \mathrm{TSP}+$ B. amyloliquifaciens; $\mathrm{P}_{2}=$ Urea $+\mathrm{KCl}+75 \%$ TSP + B. amyloliquifaciens $; \mathrm{P}_{3}=$ Urea $+\mathrm{KCl}+100 \%$ TSP (Tanpa B. amyloliquifaciens).

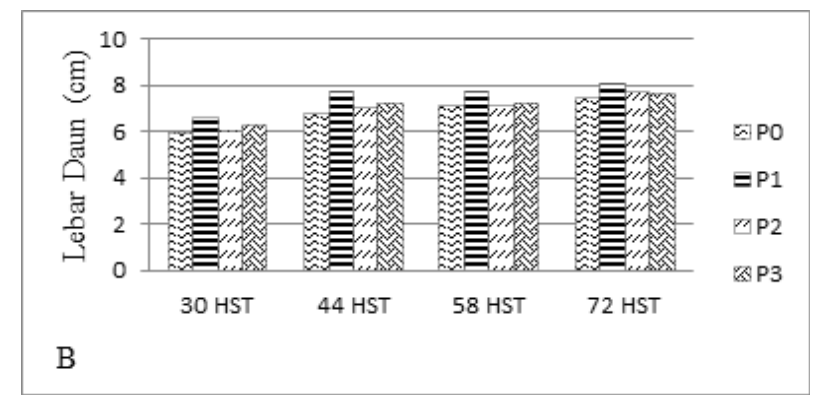

Gambar 5. Diagram pertambahan lebar daun (B) tanaman sorgum yang diberi bakteri Bacillus amyloliquefaciens dengan dosis pupuk fosfor berbeda pada 30-72 HST. $\mathrm{P}_{0}=\mathrm{Urea}+\mathrm{KCl}$ $+0 \% \mathrm{TSP}+$ B. amyloliquifaciens $; \mathrm{P}_{1}=\mathrm{Urea}+\mathrm{KCl}+50 \% \mathrm{TSP}+$ B. amyloliquifaciens; $\mathrm{P}_{2}=$ Urea $+\mathrm{KCl}+75 \%$ TSP $+B$. amyloliquifaciens; $\mathrm{P}_{3}=$ Urea $+\mathrm{KCl}+100 \%$ TSP (Tanpa B. amyloliquifaciens).

kemudian terus melambat hingga umur $58 \mathrm{HST}$ (fase berbunga) dan tidak terjadi penambahan diameter batang yang terukur pada umur 5872 HST. Sesuai Tabri dan Zubachtirodin (2013) bahwa tanaman akan tumbuh dengan cepat sampai fase pembungaan. Dari pengamatan ini terlihat bahwa pertumbuhan vegetatif dalam bentuk pertambahan diameter batang akan berhenti saat tanaman memasuki fase pertumuhan generatif yang ditandai dengan keluarnya daun bendera pada 50 HST. Hasil penelitian ini berbeda dengan Li et al. (2015) bahwa tidak ada perbedaan diameter batang pada fase perkembangan tanaman sorgum. Diameter batang umur 58-72 HST pada penelitian berkisar $\pm 23 \mathrm{~mm}$, lebih tinggi dibanding Li et al. (2015) yaitu 16,6 $\mathrm{mm}-17,4 \mathrm{~mm}$. Andriani dan Isnaini (2013) menyatakan variasi ini tergantung varietas tanaman sorgum.

\section{Pengaruh Perlakuan terhadap Pertambahan Panjang dan Lebar Daun Sorgum Mutan BMR}

Hasil penelitian menunjukkan bahwa perlakuan pemberian bakteri $B$. amyloliquefaciens dan dosis pupuk $\mathrm{P}$ yang berbeda memberikan pengaruh tidak nyata $(\mathrm{P}>0,05)$ terhadap pertambahan panjang dan lebar daun sorgum mutan BMR. Hasil penelitian ini inline dengan Sriagtula dan Sowmen (2018) bahwa sorgum mutan BMR yang di tanam pada tanah masam $\mathrm{pH} 4,7$ 
menghasilkan pertumbuhan tanaman yang hampir sama dengan galur sorgum mutan non BMR. Tidak terlihat perpedaan yang nyata pada setiap perlakuan disebabkan pengaruh $\mathrm{pH}$ tanah yang berhubungan dengan tingkat ketersediaan hara. Pada akhir penelitian $\mathrm{pH}$ tanah pada perlakuan P0, P1, P2 dan P3 hampir sama dengan nilai berturut-turut 5,$30 ; 5,47 ; 5,40$ dan 5,52 . Sorgum BMR merupakan tanaman yang memiliki kemampuan beradaptasi terhadap $\mathrm{pH}$ masam yang memiliki keterbatasan $\mathrm{P}$, sehingga pengurangan dosis pupuk $\mathrm{P}$ tidak berdampak terhadap pertumbuhan tanaman pada penelitian ini. Kriteria tanaman yang toleran terhadap $\mathrm{pH}$ masam antara lain mampu meningkatkan $\mathrm{pH}$ tanah di sekitar perakaran yang dapat mengatasi defisiensi unsur hara terutama P. Hal ini dibuktikan dengan terjadi peningkatan $\mathrm{pH}$ tanah selama penelitian dari 4,5 (awal penelitian) menjadi 5,4 (akhir penelitian). Sopandie (2014) menyatakan bahwa toleransi spesies tanaman terhadap tanah masam dengan $\mathrm{Al}$ tinggi antara lain mampu meningkatkan $\mathrm{pH}$ tanah disekitar perakaran. Faktor lain yang menyebabkan tidak berpengaruh nyata pengurangan dosis $\mathrm{P}$ dan penambahan $B$. amylliquefaciens terhadap pertambahan panjang dan lebar daun yaitu terlihat dari kandungan $\mathrm{P}$ tersedia antar perlakuan juga berbeda tidak nyata secara statistik, dengan nilai berturut-turut 5,42;7,25 ;5,88 dan 10,75 (kriteria ketersediaan P sangat rendah dan rendah). Sesuai Sopandie (2014) bahwa ketersediaan unsur hara terutama $\mathrm{P}$ dan $\mathrm{N}$ berperan dalam pertumbuhan, dan kekurangannya menjadi faktor pembatas terhadap pertumbuhan tanaman.

Pertambahan panjang dan lebar daun yang diamati pada umur 30 - 72 HST disajikan pada Gambar 4 dan 5. Semua perlakuan mengalami pertambahan panjang dan lebar yang signifikan pada setiap periode pengamatan. Pertambahan panjang dan lebar daun terjadi karena tanaman pada waktu pengamatan berada pada fase vegetatif (58 HST) dimana terjadi pertambahan jumlah dan ukuran sel. Sesuai dengan
Tabri dan Zubachtirodin (2013) bahwa fase vegetatif merupakan fase pembentukan dan perkembangan daun. Namun, pada penelitian ini masih terjadi penambahan ukuran panjang dan lebar daun setelah tanaman memasuki fase generatif (72 HST). Hal serupa juga ditemui oleh Sriagtula et al. (2016) bahwa terjadi peningkatan ukuran panjang dan lebar daun dari fase berbunga ke fase pengisian biji. Sesuai dengan Tabri dan Zubachtirodin (2013) bahwa tanaman sorgum akan tumbuh dengan cepat sampai fase pembungaan dan akan membentuk daun yang lebih lebar untuk mendukung proses pengisian biji. Sorgum manis memiliki gen pengendali daun tetap hijau (stay-green) sejak fase pengisisan biji, sehingga kandungan nitrogen pada daun lebih tinggi dan mampu meningkatkan efisiensi penggunaan radiasi. Sugg et al. (2017) menyatakan sorgum stay-green adalah tipe sorgum yang memiliki keunggulan keterlambatan fase penuaan daun, sehingga warna hijau pada daun lebih bertahan lama.

\section{KESIMPULAN}

Inokulasi B. amyloliquefaciens belum efektif meningkatkan pertumbuhan sorgum mutan BMR. Sorgum mutan BMR mampu berdaptasi pada kondisi terbatas $\mathrm{P}$. Peningkatan pertambahan tinggi tanaman, panjang dan lebar daun terjadi hingga waktu pengamatan $72 \mathrm{HST}$, namun tidak ada penambahan diameter batang setelah umur 58 HST.

\section{UCAPAN TERIMA KASIH}

Penelitian ini didanai oleh PNBP Universitas Andalas pada skema Riset Dasar Batch IV Tahun 2020, Project ID No. T/53/ UN.16.17/PT.01.03/Pangan-RD/2020. Kami mengucapkan terima kasih kepada Dr. Ir. Supriyanto yang telah mensuplai bibit sorgum mutan BMR. 


\section{DAFTAR PUSTAKA}

Andriani, A., dan M. Isnaini. 2013. Morfologi dan Fase Pertumbuhan Sorgum. Dalam; Sorgum Inovasi teknologi dan pengembangan. Penyunting Sumarno (et al.). Pusat Penelitian dan Pengembangan Tanaman Pangan, IAARD Press, Jakarta.

Bakrie, M., I. Anas., Sugiyanta, dan K. Idris. 2010. Aplikasi pupuk anorganik dan organik hayati pada budidaya padi SRI (System of Rice Intensification). J. Tanah Lingk., 12 (2): 25-32.

Campbell, N. A., J. B. Reece, dan L.G. Mitchell. 2002. Biologi, Edisi kelima Jilid1. Erlangga. Jakarta.

Dani, U. 2017. Pertumbuhan dan hasil tanaman sorgum di lahan marginal dengan pemberian pupuk akndang domba (Pemanfaatan Lahan Marginal Eks Industri Tambang Bata Merah). Jurnal Ilmu Pertanian dan Peternakan Volume 5 Nomor 1 Juli.

Du-Plessis, J. 2008. Sorghum production. Republic of South Africa Department of Agriculture. www. Nda. agric. za/ publications. Diakses 20Oktober 2019.

Dwidjoseputro, D. 2005. Dasar-Dasar Mikrobiologi. Djambatan. Jakarta.

Fitriatin, B. N., A. Yuniarti., T. Turmuktini., and F. K. Ruswandi. 2014. The Effect of Phosphate Solubilizing Microbe Producing Growth Regulators on Soil Phosphate, Growth and Yield of Maize and Fertilizer Efficiency on Ultisol. Eurasian J. of Soil Sci. Indonesia. Hal:101-107.

Getachew, D., D. Putnam., C. M. De Ben., E. J. De Peters. 2016. Potential of Sorghum as an Alternative to Corn Forage. American Journal of Plant Sciences, 07(07): 1106-1121.

Harris, R. S. dan E. Karmas. 1989. Evaluasi Gizi pada Pengolahan Bahan Pangan. Penerjemah: S. Achmadi. ITB - Press,
Bandung.

Kementan (Kementerian Pertanian). 2011. Peraturan Menteri Pertanian No. 70 Tahun 2011 tentang Pupuk Organik, Pupuk Hayati dan Pembenah Tanah. Jakarta.

Li Y., Mao P., Zhang W., Wang X., You Y., Zhao H., Zhai L., Liu G. 2015. Dynamic expression of the nutritive values in forage sorghum populations associated with white, green and brown midrid genotypes. Field Crops Research. 184 (2015) 112-122.

Mamanto, R. 2005. Pengaruh penggunaan dosis pupuk majemuk NPK Phonska terhadap pertumbuhan dan hasil kacang nagara. Agriscientiae 10 (2). Fakultas Pertanian Universitas Lambung Mangkurat. Banjarbaru.

Malusa, E., L. Sas-Paszt., J. Ciesielska. 2012. Technologies for beneficial microorganisms inocula used as biofertilizers. The Scientific Word Journal. 12 p.

Masebo, N. and M. Menamo. 2016. The Effect of Application of Different Rate of N-P Fertilizers Rate on Yield and Yield Components of Sorghum (Sorghum bicolor): Case of Derashe Woreda, SNNPR, Ethiopia. Journal of Natural Sciences Research, 6(5).

Masni, E. R., Bintang, dan P. Marpaung. 2015. Pengaruh Interaksi Bahan Mineral dan Bahan Organik Terhadap Sifat Kimia Ultisol dan Produksi Tanaman Sawi. Jurnal Online Agroekoteknologi, 3(4) (532): 1489 - 1494.

Pannacci, E. and S. Bartolini. 2018. Effect of nitrogen fertilization on sorghum for biomass production. Agronomy Research 16(5), 21462155.

Paturohman, E., M. Surahman., A. Setiawan., dan Giyanto. 2017. Efektivitas formulasi mikroba probiotik terhadap mutu fisiologis benih dan pertumbuhan jagung hibrida. Penelitian Pertanian Tanaman Pangan, 1(3). 
Prasetyo, B.H dan D. A. Suriadikarta. 2006. Karakteristik, potensi dan teknologi pengelolaan tanah ultisol untuk pengembangan pertanian lahan kering di Indonesia. Jurnal Litbang Pertanian, 25(2).

Sariwahyuni. 2012. Rehabilitasi lahan bekas tambang PT. Inco Sorowako dengan bahan organik, bakteri pelarut fosfat dan bakteri pereduksi nikel. Jurnal Riset Industri, 6(2): 149-155.

Simanjutak, W., E. Purba., dan T. Irmansyah. 2016. Respons Pertumbuhan dan Hasil Sorgum (Sorghum bicolor (L.) Moench) Terhadap Jarak Tanam dan Waktu Penyiangan Gulma. Jurnal Agroekoteknologi, 4(3) (599): 2034 2039.

Sopandie, D. 2014. Fisiologi Adaptasi Tanaman Terhadap Cekaman Abiotik Pada Agroekosistem Tropika. IPB Press. Bogor.

Sriagtula, R., Karti P. D. M. H., Abdullah, L., Supriyanto, and Astuti DA. 2016. Growth, biomass and nutrient production of brown midrib sorghum mutant lines at different harvest times. Pakistan journal of Nutrition 15(6): 524- 531.

Sriagtula, R., P. D. M. H. Karti., L. Abdullah, Supriyanto, and D. A. Astuti. 2017. Nutrient changes and in vitro digestibility in generative stage of M10-BMR sorghum mutant lines. Media Peternakan. 2: 111-117.

Sriagtula, R., dan S. Sowmen. 2018. Evaluasi Pertumbuhan dan Produktivitas Sorgum Mutan Brown midrib (Shorgum bicolor L. Moench) Fase Pertumbuhan Berbeda sebagai Pakan Hijauan pada Musim Kemarau di Tanah Ultisol. Jurnal Peternakan Indonesia. 20 (2):130-144.

Sugg, J. D., P. B. Campanili., and J. O. Sarturi. 2017. Case Study : Yield and Quality of Traditional Senescent and StayGreen Sorghum and In Situ Ruminal Disappearance of Respective Crop
Residues. Prof. Anim. Sci., vol. 33, pp. 748-755, 2017.

Suliasih, Widawati, S dan A, Muharam. 2010. Aplikasi Pupuk Organik dan Bakteri Pelarut Fosfat untuk Meningkatkan Pertumbuhan Tanaman Tomat dan Aktivitas Mikroba Tanah. J. Hort. 20(3):241-246).

Suriadikarta, Didi Ardi., Simanungkalit, R.D.M. (2006). Pupuk Organik dan Pupuk Hayati. Jawa Barat: Balai Besar Penelitian dan Pengembangan Sumber Daya Lahan Pertanian. Hal 2. ISBN 978-979-9474-57-5.

Tabri, F. dan Zubachtirodin. 2013. Budi Daya Tanaman Sorgum. Dalam; Sorgum Inovasi teknologi dan pengembangan. Penyunting Sumarno (et al.). Pusat Penelitian dan Pengembangan Tanaman Pangan, IAARD Press, Jakarta.

Talboys, P. J., D. W. Owen., J. R. Healey., P. J. Withers., and D. L. Jones. 2014. Auxin secretion by Bacillus amyloliquefaciens FZB42 both stimulates root exudation and limits phosphorus uptake in Triticum aestivum. MBC Plant Biology 14:51.

Wahyono, T., I. Sugiono, A. Jayanegara, K. G. Wiryawan, and D. A. Astuti. 2019. Nutrient Profile and In vito Degradability of New Promising Mutant Lines Sorghum as Forage in Indonesia. Advances in Animal and Veterinary Science. 7(9): 810.

Walpola, B. C. and Min-Ho Yoon. 2013. Phosphate solubilizing bacteria: Assessment of their effect on growth promotion and phosphorous uptake of mung bean (Vigna radiata [L.] R. Wilczek). Chilean Journal of Agricultural Research 73(3).

Wizna., Y. Rizal., and R. Amizar. 2017. Effect of Probiotic Waretha on Growth Performance and Efficiency of Feed Native Chickens. Conference International Seminar of Animal Nutrition \& Feed Sciences Vol. 5 p. 35. 